\title{
Melampyrum sylvaticum as a pre-diapause host plant of the scarce fritillary (Euphydryas maturna) in Finland
}

\author{
Marko Nieminen $\neq, \S$ \\ ‡ Metapopulation Research Centre, Department of Biosciences, University of Helsinki, Finland \\ $\S$ Faunatica Oy, Espoo, Finland
}

Corresponding author: Marko Nieminen (marko.nieminen@faunatica.fi)

Academic editor: Rodolphe Rougerie

Received: 08 Jul 2015 | Accepted: 13 Jul 2015 | Published: 17 Jul 2015

Citation: Nieminen M (2015) Melampyrum sylvaticum as a pre-diapause host plant of the scarce fritillary

(Euphydryas maturna) in Finland. Biodiversity Data Journal 3: e5610. doi: 10.3897/BDJ.3.e5610

\section{Abstract \\ Background}

The scarce fritillary Euphydryas (Hypodryas) maturna (L.) is included in the Habitats Directive's Annexes II and IV(a). Therefore, it is crucially important to be able to define the habitat and breeding places of $E$. maturna in a correct and unbiased way.

\section{New information}

Data on a previously unknown pre-diapause main host plant, the small cow-wheat (Melampyrum sylvaticum L.), of Euphydryas maturna in Finland is presented.

\section{Keywords}

Euphydryas maturna, Finland, Habitats Directive, host plant, Melampyrum sylvaticum, scarce fritillary 


\section{Introduction}

The scarce fritillary Euphydryas (Hypodryas) maturna (Linnaeus, 1758) is a high-profile species within the European Union, as it has been included in the Habitats Directive's (Council Directive 92/43/EEC of 21 May 1992 on the conservation of natural habitats and of wild fauna and flora) Annexes II and IV(a). Based on the Annex II, special conservation areas (i.e. Natura 2000 areas) need to be designated for E. maturna. The Annex IV lists species in need of strict protection, and those species and their breeding and resting places are protected by national legislation, which also applies to Finland. Therefore, the ability to define the habitat and breeding places of $E$. maturna in a correct and unbiased way is crucially important for both protecting the species effectively and not making uninformed administrative decisions which may be economically very costly. Euphydryas maturna is a wide-spread species in SW Finland, and it has been assessed as Least Concern by the IUCN criteria in Finland (Kaitila et al. 2010).

The species of the tribe Melitaeini, to which E. maturna belongs, feed mainly on plants containing secondary plant metabolites called iridoids (Bowers 1983, Wahlberg 2001). Iridoids are used for oviposition-plant selection, and as feeding stimulants and defensive chemicals by larvae (e.g. Bowers 1983, Nieminen et al. 2003, Wahlberg 2001). Larval host plants are the key part for the definition of breeding habitat for specialized herbivores such as E. maturna. Numerous plant species have been recorded as pre-diapause (Table 1) and/or post-diapause hosts of E. maturna throughout its range (see e.g. Wahlberg 1998, Dolek et al. 2013). In Finland, the common cow-wheat (Melampyrum pratense L.) has been recorded as the main host plant (Wahlberg 1998). Here, I present data on a previously unknown pre-diapause main host plant, the small cow-wheat (Melampyrum sylvaticum L.), of Euphydryas maturna in Finland.

\section{Table 1.}

Records of host plants used for oviposition by Euphydryas maturna females and/or for feeding by pre-diapause larvae.

\begin{tabular}{|l|l|l|}
\hline Species & Locations & References \\
\hline Fagus sylvatica & Europe & Dolek et al. 2013 \\
\hline Fraxinus angustifolia & $\begin{array}{l}\text { Carpathian Basin and SE Europe, } \\
\text { Hungary }\end{array}$ & Dolek et al. 2013, Rákosy et al. 2012 \\
\hline Fraxinus excelsior & $\begin{array}{l}\text { Austria, Czech Republic, Germany, } \\
\text { Hungary, Italy, Russia, Sweden }\end{array}$ & $\begin{array}{l}\text { Dolek et al. 2013, Eliasson 1991, Freese et al. 2006, } \\
\text { Konvicka et al. 2005, Levente 2005, Rákosy et al. } \\
\text { 2012, Tuzov et al. 2000 }\end{array}$ \\
\hline Fraxinus ornus & Carpathian Basin and SE Europe & Dolek et al. 2013, Rákosy et al. 2012 \\
\hline Ligustrum vulgare & Czech Republic, Germany, Hungary & $\begin{array}{l}\text { Dolek et al. 2013, Freese et al. 2006, Konvicka et al. } \\
\text { 2005, Rákosy et al. 2012 }\end{array}$ \\
\hline
\end{tabular}




\begin{tabular}{|c|c|c|}
\hline Lonicera & Russia & Tuzov et al. 2000 \\
\hline $\begin{array}{l}\text { Melampyrum } \\
\text { sylvaticum }\end{array}$ & Finland & This study \\
\hline $\begin{array}{l}\text { Melampyrum } \\
\text { pratense }\end{array}$ & Finland & Wahlberg 1998 \\
\hline Plantago lanceolata & Komi Republic & Gorbunov and Kosterin 2007 \\
\hline Populus alba & Russia & Tuzov et al. 2000 \\
\hline Populus tremula & Europe, Russia & Dolek et al. 2013, Tuzov et al. 2000 \\
\hline Salix caprea / Salix & Europe, Russia & Dolek et al. 2013, Tuzov et al. 2000 \\
\hline Spiraea & Russia & Tuzov et al. 2000 \\
\hline Syringa vulgaris & Russia, Sweden & $\begin{array}{l}\text { Dolek et al. 2013, Eliasson and Shaw 2003, Tuzov et } \\
\text { al. } 2000\end{array}$ \\
\hline Veronica longifolia & $\begin{array}{l}\text { Finland, Komi Republic, Krasnoyarsk } \\
\text { area, Omsk area, Novosibirsk } \\
\text { Province }\end{array}$ & Gorbunov and Kosterin 2007, Wahlberg 1998 \\
\hline Viburnum opulus & Finland, Germany, Sweden & Dolek et al. 2013, Eliasson 1991, Wahlberg 1998 \\
\hline Viola arvensis & Komi Republic & Gorbunov and Kosterin 2007 \\
\hline Viola canina & Komi Republic & Gorbunov and Kosterin 2007 \\
\hline
\end{tabular}

\section{Materials and methods}

Larval groups of E. maturna were systematically searched from an area of ca. $3.5 \mathrm{~km}^{2}$ within the municipalities of Sipoo and Pornainen in southern Finland (coordinates of the midpoint of the study area: $60.45072 \mathrm{~N}, 25.30928 \mathrm{E}$ ). All larval groups were georeferenced with GPS and photographed, and a sample of each host plant was collected for identification. Plant samples were identified by Henry Väre (Finnish Museum of Natural History, Helsinki). Fieldwork was made by MN and Kari Nupponen between August 27 and September 11 in 2014.

\section{Taxon treatment}

\section{Euphydryas maturna (Linnaeus, 1758)}

\section{Materials}

a. scientificName: Euphydryas maturna; order: Lepidoptera; family: Nymphalidae; taxonRank: species; genus: Euphydryas; specificEpithet: maturna; country: Finland; stateProvince: Uusimaa; municipality: Sipoo; locality: Brusas; verbatimElevation: $60 \mathrm{~m}$; verbatimCoordinates: $60^{\circ} 26.73^{\prime} \mathrm{N} 25^{\circ} 17.95^{\prime} \mathrm{E}$; verbatimLatitude: $60^{\circ} 26.73^{\prime} \mathrm{N}$; 
verbatimLongitude: $25^{\circ} 17.95$ 'E; decimalLatitude: 60.4455 ; decimalLongitude: 25.2992 ; samplingProtocol: visual search; eventDate: 2014-08-27/09-11; individualCount: 120; lifeStage: larva; occurrenceRemarks: number of larval groups counted (with unknown number of larvae per group); recordedBy: Marko Nieminen; identifiedBy: Marko Nieminen; dateldentified: 2014; language: en; basisOfRecord: Photographed; source: marko.nieminen@faunatica.fi

b. $\quad$ scientificName: Euphydryas maturna; order: Lepidoptera; family: Nymphalidae; taxonRank: species; genus: Euphydryas; specificEpithet: maturna; country: Finland; stateProvince: Uusimaa; municipality: Pornainen; locality: Mäkelä; verbatimElevation: 60 $\mathrm{m}$; verbatimCoordinates: $60^{\circ} 27.32^{\prime} \mathrm{N} 25^{\circ} 17.94^{\prime} \mathrm{E}$; verbatimLatitude: $60^{\circ} 27.32^{\prime} \mathrm{N}$; verbatimLongitude: $25^{\circ} 17.94$ 'E; decimalLatitude: 60.4554 ; decimalLongitude: 25.2991 ; samplingProtocol: visual search; eventDate: 2014-08-27/09-11; individualCount: 23; lifeStage: larva; occurrenceRemarks: number of larval groups counted (with unknown number of larvae per group); recordedBy: Marko Nieminen; identifiedBy: Marko Nieminen; dateldentified: 2014; language: en; basisOfRecord: Photographed; source: marko.nieminen@faunatica.fi

c. scientificName: Euphydryas maturna; order: Lepidoptera; family: Nymphalidae; taxonRank: species; genus: Euphydryas; specificEpithet: maturna; country: Finland; stateProvince: Uusimaa; municipality: Pornainen; locality: Honkasenkalliot; verbatimElevation: $60 \mathrm{~m}$; verbatimCoordinates: $60^{\circ} 26.51^{\prime} \mathrm{N} 25^{\circ} 19.27^{\prime} \mathrm{E}$; verbatimLatitude: $60^{\circ} 26.51$ ' $\mathrm{N}$; verbatimLongitude: $25^{\circ} 19.27 \mathrm{E}$; decimal Latitude: 60.4419 ; decimalLongitude: 25.3211; samplingProtocol: visual search; eventDate: 2014-09-10/11; individualCount: 24; lifeStage: larva; occurrenceRemarks: number of larval groups counted (with unknown number of larvae per group); recordedBy: Kari Nupponen; identifiedBy: Kari Nupponen; dateldentified: 2014; language: en; basisOfRecord: Photographed; source: marko.nieminen@faunatica.fi

\section{Ecology}

Totally 167 larval groups were located, all on Melampyrum spp. (Fig. 1). In some cases, at least two original larval groups had probably merged. All larval groups were either in clear-cuts (usually close to the edges, and sometimes within the forest 0-5 $\mathrm{m}$ from the clear-cut [Figs 2, 4]), in thinned and light commercial forests (Figs 3, 4), or in open powerline corridors (Fig. 5).

Due to the dry conditions in July and August, many or even all host plants had withered especially in open rocky areas. Therefore, reliable identifications based on plant morphology were possible for 121 samples. Of the identified samples, 30 plants $(25 \%)$ were $M$. pratense and 91 plants (75\%) M. sylvaticum. In addition, three larval groups have been found in the same area in the autumn of 2013, all on M. sylvaticum (JariPekka Kaitila, personal observations). 


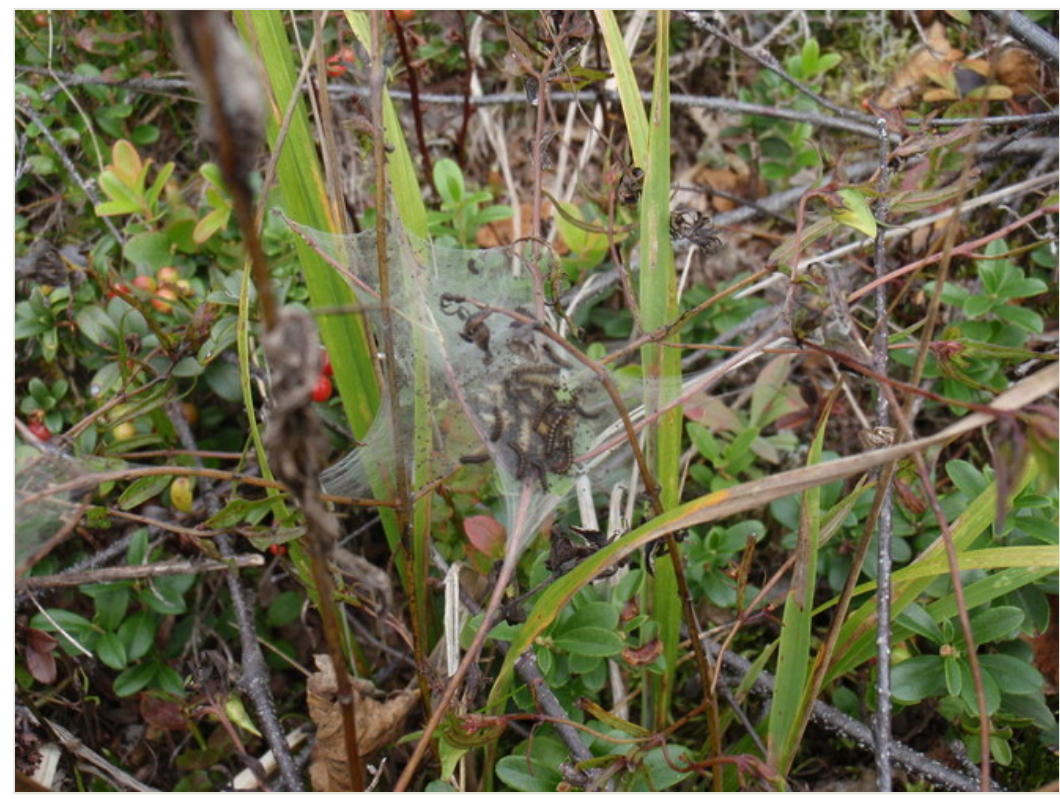

Figure 1.

Larval web of Euphydryas maturna on Melampyrum sylvaticum in Sipoo, S Finland (November $2^{\text {nd }}$, 2014).

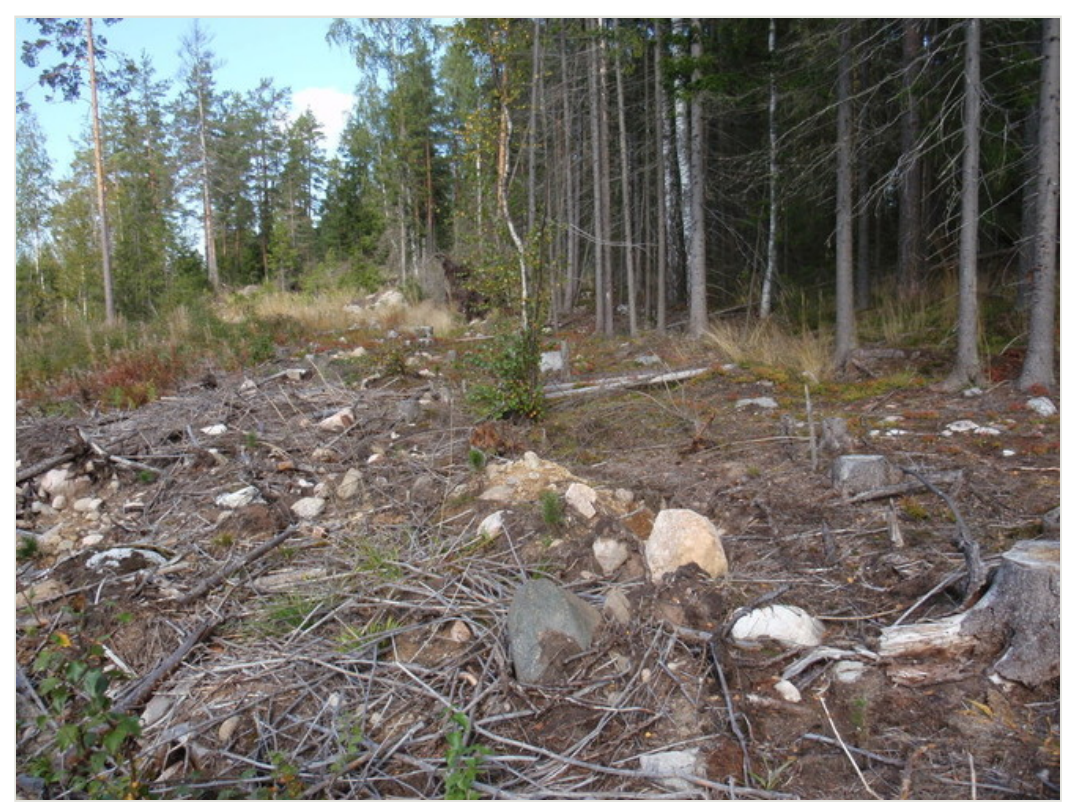

\section{Figure 2.}

Clear-cut edge habitat of Euphydryas maturna. Clear-cut edges typically remain suitable for breeding for some years only until they become overgrown by tall grasses and tree seedlings. 


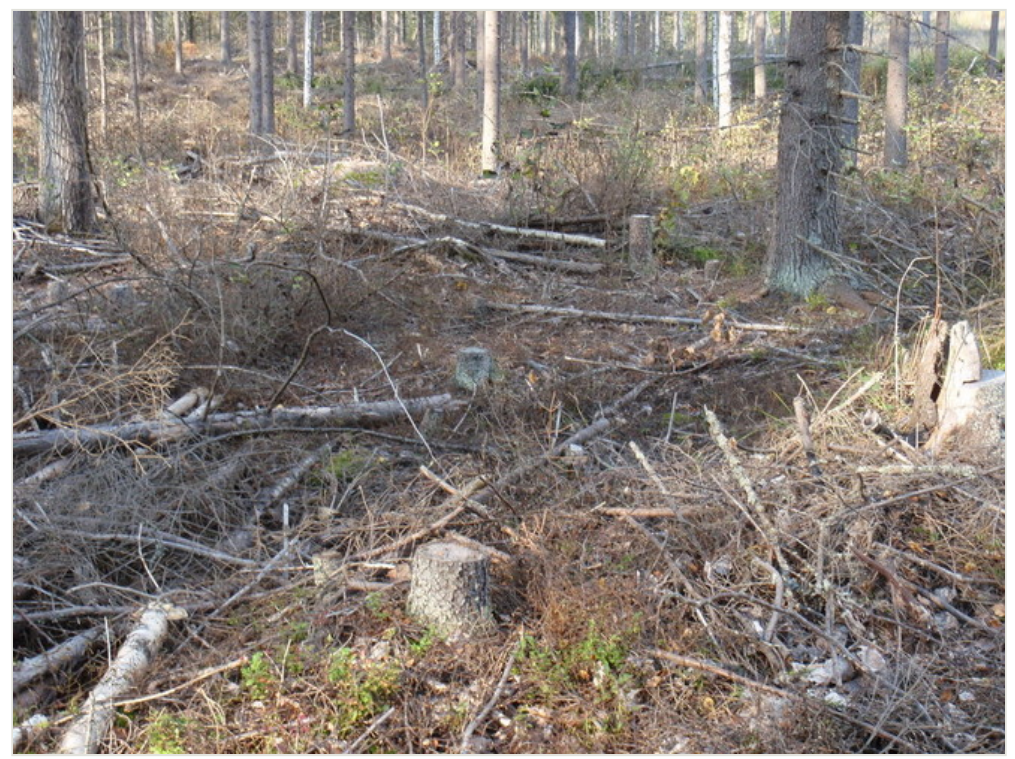

Figure 3.

Euphydryas maturna habitat in a commercial, thinned spruce-dominated forest. Such habitats are probably suitable after thinning for several years.

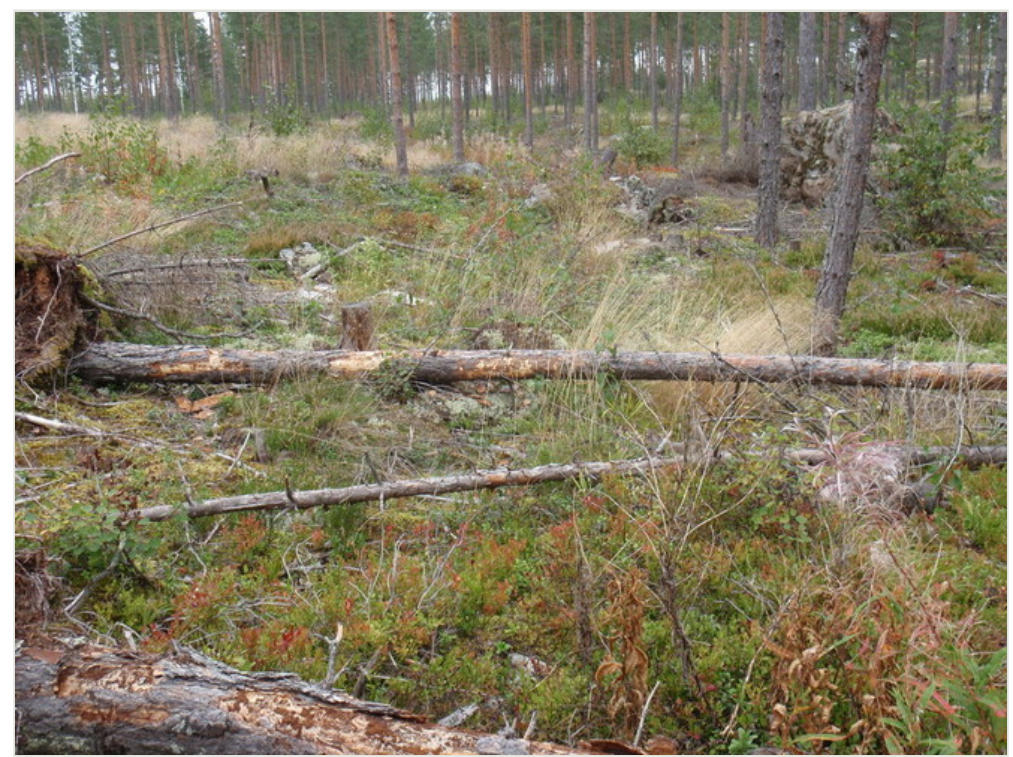

Figure 4.

Euphydryas maturna habitat in a commercial, thinned pine-dominated forest with ca. 30-year old trees, and in a clear-cut edge. This kind of forest habitat is probably suitable after thinning for several years, but longer than spruce-dominated forests (Fig. 3). Also, edge habitats in these relatively dry habitats overgrow somewhat slower than in moister edges (Fig. 2). 


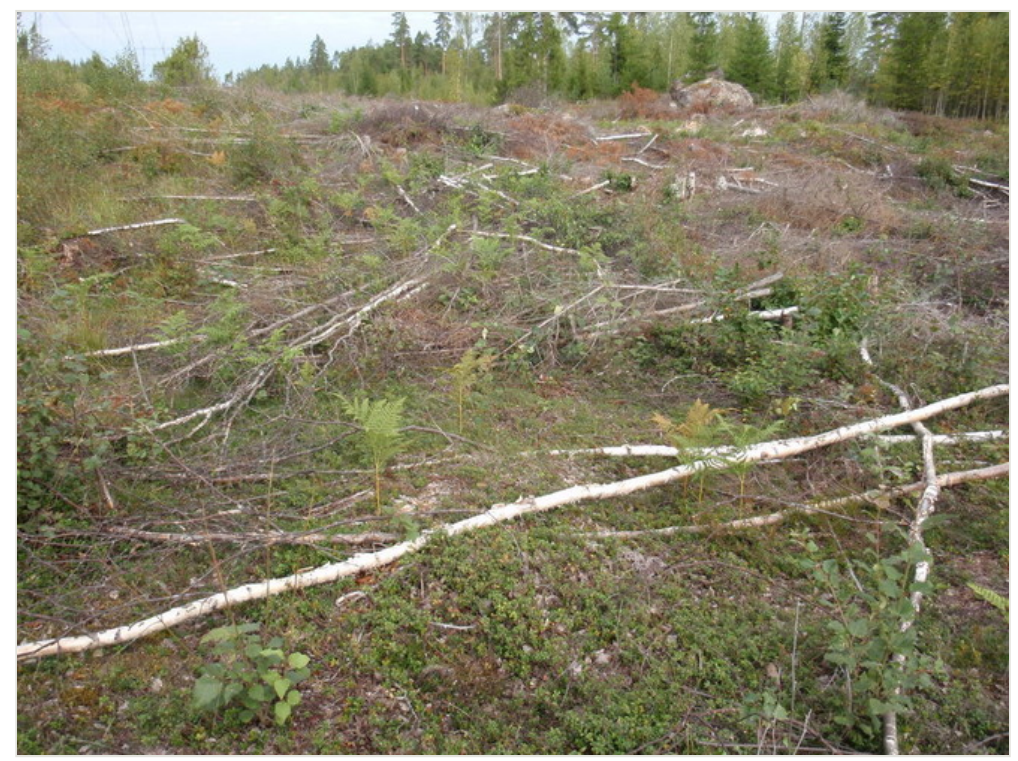

Figure 5.

Powerline habitat of Euphydryas maturna. Vegetation under powerlines is kept open continuously, so powerline habitats may function both as breeding places and dispersal corridors.

\section{Discussion}

The regional host plant use of $E$. maturna is highly variable throughout its range (Table 1), but is apparently restricted to only a couple of preferred species used for oviposition within any particular region. For example, Fraxinus is the most regularly used oviposition-plant genus in the Central Europe (e.g. Cizek and Konvicka 2005, Levente 2005, Freese et al. 2006, Dolek et al. 2013), whereas lower plants such as Veronica longifolia are often used in the eastern areas (e.g. Korshunov and Gorbunov 1995, Gorbunov and Kosterin 2007). However, it seems common that the post-diapause larvae feed on a wider spectrum of host plants than are used for oviposition (Gorbunov and Kosterin 2007, Dolek et al. 2013), for example Plantago lanceolata is frequently used after diapause in Austria (Freese et al. 2006). There may be regional differences in preference also within the Finnish range, as all females observed during their search for oviposition-plants ignored $M$. sylvaticum in a study performed about $200 \mathrm{~km}$ to the northeast of this study area (Wahlberg 1998). Moreover, the importance of other host plants than $M$. pratense and $M$. sylvaticum still remain uncertain throughout Finland.

The use of M. sylvaticum as a host plant (Fig. 1) considerably increases both the suitable breeding area of $E$. maturna and the amount of resources available for it. In the study area, the increase in both of these variables must be manyfold, but remains to be quantified. Melampyrum pratense is much more vulnerable to desiccation and withering because it 
grows in drier sites than M. sylvaticum. The ability to use both of these Melampyrum species is extremely important in dry summers such as 2014 , when more than $90 \%$ of host plants had withered in several sites. That high rate of dry host plants has likely increased mortality of groups of small larvae and may also decrease overwintering success due to starvation of larvae, which are common phenomena in another larval group-forming species Melitaea cinxia in Finland (e.g. Kuussaari et al. 2004).

Some leaves of Vaccinium myrtillus had been eaten within some larval webs. Even though I could not confirm that $E$. maturna larvae had eaten them, it is, however, likely because other herbivorous larvae were not observed and Melampyrum individuals were almost completely dry in and around these larval nests. Therefore, larvae may have used $V$. myrtillus to rescue themselves from starvation. The same explanation may apply to the odd

observations of larvae feeding on e.g. Fagus, Populus and Salix regularly referred to in the literature (e.g. Korshunov and Gorbunov 1995, Gorbunov and Kosterin 2007, Dolek et al. 2013). A further explanation for 'odd' host records is that the actual host plants often become consumed completely leaving only non-host plants visible among and next to larval webs.

\section{Acknowledgements}

I thank Kari Nupponen for help in the field work and collecting information on host use in Russia and adjacent areas, Henry Väre for the identification of host plant samples, and Jari-Pekka Kaitila for his observations on M. sylvaticum as a host plant of E. maturna in the same area in 2013. The field work was financed by Lemminkäinen Infra Oy.

\section{References}

- Bowers MD (1983) The role of iridoid glycosides in host-plant specificity of checkerspot butterflies. Journal of Chemical Ecology 9 (4): 475-493. DOI: $10.1007 /$ bf00990220

- $\quad$ Cizek O, Konvicka M (2005) What is a patch in a dynamic metapopulation? Mobility of an endangered woodland butterfly, Euphydryas maturna. Ecography 28 (6): 791-800. DOI: $10.1111 / j .2005 .0906-7590.04268 . x$

- Dolek M, Freese-Hager A, Geyer A, Balletto E, Bonelli S (2013) Multiple oviposition and larval feeding strategies in Euphydryas maturna (Linné, 1758) (Nymphalidae) at two disjoint European sites. Journal of Insect Conservation 17 (2): 357-366. DOI: $10.1007 /$ s10841-012-9516-X

- $\quad$ Eliasson C (1991) Studier av boknätfjärilens, Euphydryas maturna (Lepidoptera. Nymphalidae, förekomst och biologi i Västmanland. Entomologisk tidskrift 112: 113-124.

- $\quad$ Eliasson CU, Shaw MR (2003) Prolonged life cycles, oviposition sites, foodplants and Cotesia parasitoids of Melitaeini butterflies in Sweden. Oedippus 21: 1-52.

- Freese A, Benes J, Bolz R, Cizek O, Dolek M, Geyer A, Gros P, Konvicka M, Liegl A, Stettmer C (2006) Habitat use of the endangered butterfly Euphydryas maturna and 
forestry in Central Europe. Animal Conservation 9 (4): 388-397. DOI: $10.1111 /$ j.1469-1795.2006.00045.x

- $\quad$ Gorbunov P, Kosterin O (2007) The butterflies (Hesperioidea and Papilionoidea) of North Asia (Asian part of Russia) in nature. Rodina \& Fodio, Moscow, 408 pp.

- Kaitila JP, Nupponen K, Kullberg J, Laasonen EM (2010) Butterflies and moths. In: Rassi P, Hyvärinen E, Juslén A, Mannerkoski I (Eds) The 2010 Red List of Finnish Species. Ympäristöministeriö \& Suomen ympäristökeskus, Helsinki, 685 pp. [ISBN 978-952-11-3806-5].

- $\quad$ Konvicka M, Cizek O, Filipova L, Fric Z, Benes J, Krupka M, Zamecnik J, Dockalova Z (2005) For whom the bells toll: Demography of the last population of the butterfly Euphydryas maturna in the Czech Republic. Biologia 60: 551-557.

- Korshunov YP, Gorbunov PY (1995) Butterflies of the Asian part of Russia. A handbook. University Press, Ekaterinburg, 202 pp. [In Russian].

- Kuussaari M, van Nouhuys S, Hellmann J, Singer MC (2004) Larval Biology of Checkerspots. In: Ehrlich PR, Hanski I (Eds) On the Wings of Checkerspots: A Model System for Population Biology. Oxford University Press, New York, 408 pp. [ISBN 978-0-19-515827-4].

- Levente Á (2005) Biomonitoring of the butterfly fauna in the Drava region (Lepidoptera: Diurna). Natura Somogyiensis 7: 63-73.

- $\quad$ Nieminen M, Suomi J, Nouhuys SV, Sauri P, Riekkola M (2003) Effect of iridoid glycoside content on oviposition host plant choice and parasitism in a specialist herbivore. Journal of Chemical Ecology 29 (4): 823-844. DOI: 10.1023/ a:1022923514534

- $\quad$ Rákosy L, Pecsenye K, Mihali C, Tóth A, Varga Z (2012) Taxonomic review of Euphydryas maturna (Linnaeus, 1758) (Lepidoptera, Nymphalidae) with description of a new subspecies from Dobrogea (Romania) and notes on conservation biology. Acta Zoologica Academiae Scientiarum Hungaricae 58: 145-161.

- Tuzov VK, Bogdanov PV, Churkin SV, Dantchenko AV, Devyatkin AL, Murzin VS, Samodurov GD, Zhdanko AB (2000) Guide to the butterflies of Russia and adjacent territories (Lepidoptera, Rhopalocera). Volume 2: Libytheidae, Danaidae, Nymphalidae, Riodinidae, Lycaenidae. Pensoft, Sofia \& Moscow, $581 \mathrm{pp}$.

- Wahlberg N (1998) The life history and ecology of Euphydryas maturna (Nymphalidae: Melitaeini) in Finland. Nota lepidopterologica 1998: 154-169.

- Wahlberg N (2001) The Phylogenetics And Biochemistry Of Host-Plant Specialization In Melitaeine Butterflies (Lepidoptera: Nymphalidae). Evolution 55 (3): 522-537. DOI: 10.1 111/j.0014-3820.2001.tb00786.x 